\title{
The Influence of Parenting Pattern on Cadet Prosocial Behaviour Civil Aviation and Safety Engineering of Medan
}

\author{
Susi Diriyanti Novalina ${ }^{*}$, Rossi Peter $^{2}$, Mahadi $^{3}$ \\ ${ }^{1,2,3)}$ Aviation Engineering and Safety Academy, Medan, Indonesia \\ *susidiriyantinovalina@gmail.com
}

\begin{abstract}
Aggressive actions in physical or verbal committed by a Student or group of Student against another Student or a group of student in education must be resolved by increasing prosocial behavior of students. Prosocial behavior is an act that has positive social impact directing to welfaring others and oneself both physical and psychological. Parenting patterns of Cadet Supervisor play an important role in prosocial behavior. This study aims to analyze the effect of Parenting Pattern of Cadet Supervisor to Cadet Prosocial behavior of Medan Aviation Polytechnic. The study population was all Cadets of the Medan Aviation Polytechnic, study subject was taken by using simple random sampling method with total 200 cadets. Statistical Test Results show that Parenting Pattern Of Cadet Supervisor has significant Effect on the formation and development of Prosocial behavior, thus parenting pattern has positive influence in prosocial behavior of cadets which furthermore helps cadets to control their actions based on public values and norms.
\end{abstract}

Keywords: prosocial behavior, parenting pattern, cadets supervisor

\section{Introduction}

The emotional touches will become increasingly rare "goods" in industrial revolution 4.0 era. Schwab [1] in his book "The Fourth Industrial Revolution" explained that the emotion management ability became important competencies in the industrial revolution 4.0. Sincere attitude, understanding other people needs, empathy are Competencies that cannot be replaced by the most sophisticated robots and technology. All of these competencies only be done by humans who have the emotion management ability. The ability for managing emotions is an important attribute in the fourth industrial revolution. Through good emotional management, will enable people to be more innovative and enable them to become agents of change. Through this emotional management, an individual will developing positive behaviors such as sharing, helping, donating, cooperating, and being honest. These forms of positive behavior are called prosocial behavior by mussen.

Prosocial behavior is an act for helping others who are motivated by personal interests without expecting anything. Wrightsman and Deaux explained that prosocial behavior is people behavior that has positive social consequences directed to the physical and psychologicall welbeing of other people, not directly give benefit to the actor of prosocial behavior. One method for diminished case of violence such as bullying among students in education institution is develop prosocial behavior. In Indonesia, data of incidents of violence such as bullying by the Indonesian Child Protection Commission [KPAI] provides data that 
from 2011 to 2017 there were more than 26,000 reported cases of bullying. 34\% of them are cases of children dealing with many laws due to harassment.

For improving maximum achievement of aviation human resources, maximum coaching process is also needed in order to deal with developments in fourth industrial revolution. Related to this, the maximum coaching process is through good parenting style or method. Through good parenting style, cadets will be able motivating themselves, handle their frustration, control the negative emotion, set the mood, empathize and the ability to work together in a group [2]. Parenting style is an act of interaction to provide guidance, education in the life of an individual in order to achieve successful life. Euis [3] argues that parenting is a series of intensive interactions between parents and children so that the child obtain life skills. According to the Cadet parenting style guidelines of the Ministry of Transportation Number PK.2 / BPSDMP-2018, explaining that there are Methods or Patterns for empowering cadets: Instructive, Educational, Suggestive, Persuasive, Giving Trust, Granting Sanctions, Habituating, group and organizational discussions. Through these various methods, nurturing process can develop the social behavior of cadets, as an impact they will be able to control themselves in accordance with the values of the community in helping and caring each other.

\section{Prosocial Behavior}

Batson define Prosocial Behavior [3] as very broad behavior category, including every action that helps or designed to help others, Dividio et al. [4] also considers that prosocial behavior is behavior that voluntarily aims to help others. Prosocial behavior is influenced by situational and social factor, such as presence of other individuals who influence one another. Another factor influencing prosocial behavior is the mood of the helper. A person's relationship with another person can also influence to determine prosocial actions. Personality characteristics are also important for determining prosocial behavior, especially those related to situational factors. Apart from situational factor, people quite often look for opportunities to get involved in this prosocial action. Determinants of this behavior are also important to consider, prosocial behavior can certainly help students to achieve responsible social behavior, learn to participate in social life and uphold community values in their behavior. Based on this explanation, Prosocial Behavior able to prevent bullying that occur in education institution. In line with this expression, Caprara revealed that the way to suppress bullying is to increase prosocial behavior, by increasing the frequency of prosocial behavior, iolent behavior such as bullying can be suppressed.

\section{Parenting Pattern of Cadet Supervisor and Prosocial Behavior}

Medan Aviation Polytechnic is one of the Education and Training institutions located in the Medan city, this institution has vision to educate and train students called Taruna to be an expert in aviation engineering and safety. In their daily life at the dormitory, cadets are trained by cadets supervisors. This research will highlight the parenting methods provided by the cadet supervisors and their effect on prosocial behavior. Parenting is an act of interaction to provide guidance, education in the life of an individual in order to obtain successful lifeskill. Euis [2004] considers that Parenting is a series of intensive interactions between parents and children so that the child has life skills. In connection with the definition of parenting, it is expected that the parenting method of cadet supervisor will increase awareness, mutual support, cooperation between cadets. The action that has been explained also called prosocial behavior which is ultimately expected to suppress bullying that occur between cadets. 


\section{Research Method}

The subjects in this study are all cadet in Medan Aviation Polytechnic. Samples size were obtained as much as $50 \%$ of the total cadet. The current total cadets are 400 person, so the amount of samples size is 200 cadets. 200 cadets as research subject consist of three categories, namely fisrt year, second year, and thisrd year, the sampling method applied is stratified random sampling, which determines the sample randomly for each categories.

Design of this research is quantitative research with correlational quantitative research. Correlational research is research that is intended to determine whether there is a relationship between two or several variables. With this technique a researcher can relate one variable to another variable.

Variables in this study consisted of two variables, namely independent variable and dependent variable. The independent variable $[\mathrm{X}]$ is parenting method and dependent variable [Y] is prosocial behavior. Data for Parenting style of cadet supervisors was obtained from the Parenting style quesionaire designed based on the Parenting Method sourced from the Guidelines for the Parenthing of the Badan Pengembangan Sumber Daya Manusia Perhubungan (BPSDM),Ministry of Transportation No.PK.2/BPSDMP-2018. The questionnaire consisted of four answer choices which were very appropriate, appropriate, not suitable and very inappropriate. Prosocial Behavior Data was obtained from a prosisal behavior questionnaire which was designed based on form of prosocial behavior such as: sharing, that is willingness to share with others both in joy and sorrow situations, cooperating that is the willingness to cooperate with others for the purpose of creating goals, Helping namely awareness to help others who are struggling, Donating is willingness to donate, giving a part of their belongings to people in need and Honesty is willingness to be honest or not to cheat others.

To measure the validity of the questionnaire is using the pearson product moment formula from based on the value of the Corrected item total Correlation [rit]. Besides validity, reliability is also determined which mean the extent to which the results of a measurement can be trusted. By using statistical program, a minimum value of rit $=0.3$ is obtained and the alpha cronbach reliability of Prosocial and Parenting questionaire is 0.9. and then to examine the effect of parenting on prosocial behavior used the Linear Regression Test.

\section{Results and Discussion}

Research Subjects with a total subject of 200 cadet, consisting of Aircraft Engineering cadet (TPU), Air Traffic Control cadet (PLLU), Telecommunications and Air Navigation Engineering cadet (TNU), and Airport Electrical Engineering cadet (TLB), the following data distribution by majors:

Table 1. Subject Distribution by Majors

\begin{tabular}{llll}
\hline No & Major & N & Percentage \\
\hline $\mathbf{1}$ & TPU & 71 & $35,5 \%$ \\
$\mathbf{2}$ & PLLU & 26 & $13 \%$ \\
$\mathbf{3}$ & TNU & 45 & $22,5 \%$ \\
$\mathbf{4}$ & TLB & 58 & $29 \%$ \\
\hline
\end{tabular}

From the Prosocial Behavior and Parenting style Scale, All data are divided into five groups, namely: Very High, High, Medium, Low and Very Low, and table 2 shows ranges of scores for each category: 
Table 2. Description Based on Parenting Score Categories and Prosocial Behavior

\begin{tabular}{ccllr}
\hline No & Variabel & Range & Category & N [\%] \\
\hline $\mathbf{1}$ & Parenting Style & $\mathrm{X}<89$ & Very Low & $0[0 \%]$ \\
& & $89 \leq \mathrm{X}<115$ & Low & $1[5 \%]$ \\
& $115 \leq \mathrm{X}<140$ & Medium & $59[29,5 \%]$ \\
& $140 \leq \mathrm{X}<166$ & High & $106[53 \%]$ \\
& & $\mathrm{X} \geq 166$ & Very High & $34[17 \%]$ \\
\hline $\mathbf{2}$ & Prosocial Behavior & $\mathrm{X}<72$ & Very Low & $0[0 \%]$ \\
& & $72 \leq \mathrm{X}<92$ & Low & $0[0 \%]$ \\
& & $92 \leq \mathrm{X}<113$ & Medium & $18[9 \%]$ \\
& & $\mathrm{X} \geq 133<\mathrm{X}<133$ & High & $106[53 \%]$ \\
& & Very High & $76[38 \%]$ \\
\hline
\end{tabular}

Based on table 2, according to the Research Subject, 34 (17\%) people rated that the Parenting style applied by cadet supervisor were in the very high category, $106(53 \%)$ in the high category, $59(29.5 \%)$ in the moderate category, $1(95 \%)$ in the low category. For the Prosocial Behavior variable, $76(38 \%)$ subjects considered that they had implemented prosocial behavior in very high category, 106 (53\%) in high category, and $18(9 \%)$ the moderate category.

Table 3. Description of Aspects of The Variables Based on Score Categories

\begin{tabular}{|c|c|c|c|c|c|c|}
\hline No. & Variable & Aspect & Range [R] & Category & $\mathbf{N}$ & $\%$ \\
\hline \multirow[t]{26}{*}{1} & Parenting & Instructive & $\geq 29$ & ST & 61 & $30,5 \%$ \\
\hline & Style & & $25 \leq \mathrm{R}<29$ & $\mathrm{~T}$ & 98 & $49 \%$ \\
\hline & & & $20 \leq \mathrm{R}<25$ & $\mathrm{~S}$ & 40 & $20 \%$ \\
\hline & & & $16 \leq \mathrm{R}<20$ & $\mathrm{R}$ & 1 & $0,5 \%$ \\
\hline & & & $<1 \overline{6}$ & SR & 0 & $0 \%$ \\
\hline & & Edukative & $\geq 29$ & ST & 36 & $18 \%$ \\
\hline & & & $25 \leq \mathrm{R}<29$ & $\mathrm{~T}$ & 95 & $47,5 \%$ \\
\hline & & & $20 \leq \mathrm{R}<25$ & $\mathrm{~S}$ & 62 & $31 \%$ \\
\hline & & & $16 \leq \mathrm{R}<20$ & $\mathrm{R}$ & 7 & $3,5 \%$ \\
\hline & & & $<1 \overline{6}$ & SR & 0 & $0,5 \%$ \\
\hline & & Sugestive and & $\geq 26$ & $\mathrm{VH}$ & 67 & $33,5 \%$ \\
\hline & & Persuasive & $22 \leq \mathrm{R}<26$ & $\mathrm{H}$ & 93 & $46,5 \%$ \\
\hline & & & $18 \leq \mathrm{R}<22$ & M & 38 & $19 \%$ \\
\hline & & & $14 \leq \mathrm{R}<18$ & $\mathrm{~L}$ & 2 & $1 \%$ \\
\hline & & & $<14$ & VL & 0 & $0 \%$ \\
\hline & & Giving Trust & $\geq 20$ & VH & 35 & $17,5 \%$ \\
\hline & & & $17 \leq \mathrm{R}<20$ & $\mathrm{H}$ & 113 & $56,5 \%$ \\
\hline & & & $14 \leq \mathrm{R}<16$ & $\mathrm{M}$ & 45 & $22,5 \%$ \\
\hline & & & $11 \leq \mathrm{R}<14$ & $\mathrm{~L}$ & 7 & $3,5 \%$ \\
\hline & & & $<1 \overline{0}$ & VL & 0 & $0 \%$ \\
\hline & & Granted Sanctions & $\geq 20$ & $\mathrm{VH}$ & 48 & $24 \%$ \\
\hline & & & $17 \leq \mathrm{R}<20$ & $\mathrm{H}$ & 90 & $45 \%$ \\
\hline & & & $14 \leq \mathrm{R}<16$ & $\mathrm{M}$ & 56 & $28 \%$ \\
\hline & & & $11 \leq \mathrm{R}<14$ & $\mathrm{~L}$ & 6 & $3 \%$ \\
\hline & & & $<10$ & VL & 0 & $0 \%$ \\
\hline & & Guidance and & $\geq 13$ & $\mathrm{VH}$ & 61 & $30,5 \%$ \\
\hline
\end{tabular}




\begin{tabular}{|c|c|c|c|c|c|c|}
\hline No. & Variable & Aspect & Range [R] & Category & $\mathbf{N}$ & $\%$ \\
\hline & & Habituation & $11 \leq \mathrm{R}<13$ & $\mathrm{H}$ & 103 & $51,5 \%$ \\
\hline & & & $9 \leq \mathrm{R}<11$ & M & 29 & $14,5 \%$ \\
\hline & & & $7 \leq \mathrm{R}<9$ & $\mathrm{~L}$ & 6 & $3 \%$ \\
\hline & & & $<7$ & VL & 1 & $0,5 \%$ \\
\hline & & Group and & $\geq 29$ & $\mathrm{VH}$ & 30 & $15 \%$ \\
\hline & & Organization & $25 \leq \mathrm{R}<29$ & $\mathrm{H}$ & 85 & $42,5 \%$ \\
\hline & & activities & $20 \leq \mathrm{R}<25$ & M & 80 & $40 \%$ \\
\hline & & & $16 \leq \mathrm{R}<20$ & $\mathrm{~L}$ & 5 & $2,5 \%$ \\
\hline & & & $<1 \overline{6}$ & VL & 0 & $0 \%$ \\
\hline \multirow[t]{25}{*}{2.} & Prosocial & Sharing & $\geq 26$ & $\mathrm{VH}$ & 74 & $37 \%$ \\
\hline & Behavior & & $22 \leq \mathrm{R}<26$ & $\mathrm{H}$ & 112 & $56 \%$ \\
\hline & & & $18 \leq \mathrm{R}<22$ & M & 14 & $7 \%$ \\
\hline & & & $14 \leq \mathrm{R}<18$ & $\mathrm{~L}$ & 0 & $0 \%$ \\
\hline & & & $<1 \overline{4}$ & VL & 0 & $0 \%$ \\
\hline & & Cooperating & $\geq 29$ & $\mathrm{VH}$ & 81 & $40,5 \%$ \\
\hline & & & $25 \leq \mathrm{R}<29$ & $\mathrm{H}$ & 104 & $52 \%$ \\
\hline & & & $20 \leq \mathrm{R}<25$ & M & 15 & $7,5 \%$ \\
\hline & & & $16 \leq \mathrm{R}<20$ & $\mathrm{~L}$ & 0 & $0 \%$ \\
\hline & & & $<1 \overline{6}$ & VL & 0 & $0 \%$ \\
\hline & & Helping & $\geq 23$ & $\mathrm{VH}$ & 176 & $88 \%$ \\
\hline & & & $19 \leq \mathrm{R}<23$ & $\mathrm{H}$ & 23 & $11,5 \%$ \\
\hline & & & $16 \leq \mathrm{R}<19$ & $\mathrm{M}$ & 1 & $0,5 \%$ \\
\hline & & & $12 \leq \mathrm{R}<16$ & $\mathrm{~L}$ & 0 & $0 \%$ \\
\hline & & & $<12$ & VL & 0 & $0 \%$ \\
\hline & & Donating & $\geq 29$ & $\mathrm{VH}$ & 82 & $41 \%$ \\
\hline & & & $25 \leq \mathrm{R}<29$ & $\mathrm{H}$ & 91 & $45,5 \%$ \\
\hline & & & $20 \leq \mathrm{R}<25$ & M & 26 & $13 \%$ \\
\hline & & & $16 \leq \mathrm{R}<20$ & $\mathrm{~L}$ & 1 & $0,5 \%$ \\
\hline & & & $<1 \overline{6}$ & VL & 0 & $0 \%$ \\
\hline & & Honesty & $\geq 23$ & $\mathrm{VH}$ & 85 & $42,5 \%$ \\
\hline & & & $19 \leq \mathrm{R}<23$ & $\mathrm{H}$ & 95 & $47,5 \%$ \\
\hline & & & $16 \leq \mathrm{R}<19$ & $\mathrm{M}$ & 18 & $9 \%$ \\
\hline & & & $12 \leq \mathrm{R}<16$ & $\mathrm{~L}$ & 2 & $1 \%$ \\
\hline & & & $<12$ & VL & 0 & $0 \%$ \\
\hline
\end{tabular}

Based on Table 3, aspects of parenting with the very highest category are at most suggestive and persuasive aspects as many as 67 person or $33.5 \%$, while this aspect means that cadet supervisor at Medan Aviation Polytechnic have tried to provide constructive advice in achieve behavioral change. The aspect of parenting style that has very high category that has the lowest amount is in the aspects of discussion and organization, this means that the cadet supervisor of the cadets need to further develop the ability of cadets to work in a groups or organization and the ability to work together in mutual support. There are also aspects that have low category, namely the educational aspects and giving trust, this means that important to develop the discussion activities that encourage and develop the ability of cadets to increase academic achievement. Table 3 also show that prosocial behavior is in the very high category at most in the aspect of helping, this data means that the cadet of Poltekbang Medan already has a willingness to provide assistance to other cadets who are experiencing difficulties. Besides that, the category is very high at least in the aspect of Sharing, this means cadets need to develop their ability to share and provide support to other cadets who have problems both in education and non-education. 
Linear regression test in this research aims to examine the effect of parenting style of cadet supervisor on prosocial behavior of cadets. Based on linear regression analysis, the following results are obtained:

Table 4. Statistics of Significant Test

\begin{tabular}{llllll}
\hline No & Variables & Mean \pm SD & N & r & Sig.p \\
\hline 1 & Parenting style & $149.8 \pm 14.5$ & 200 & 0.495 & 0.00 \\
2 & Prosocial Behavior & $129.5 \pm 14.5$ & 200 & & \\
\hline
\end{tabular}

Pearson Correlation Data shows that the value of $r=0.495$ with a value of $p=0,000$, this correlation value means that there is a significant positive relationship between parenting style with prosocial behavior, the higher score of the parenting style given to cadets, the higher the prosocial behavior that cadets show.

Table 5. Analysis Coefficients of Linear Regression

\begin{tabular}{lllllll}
\hline No & Model & Coefficient & t & Sig & F & Sig \\
\hline $\mathbf{1}$ & Constant & 67,352 & 8,624 & 0,000 & 64,262 & 0,000 \\
$\mathbf{2}$ & Parenting Style & 0,415 & 8,016 & 0,000 & & \\
\hline
\end{tabular}

Table 5 shows that the value of $F$ test and the coefficient of linear regression equation, the $F$ value $=64.262$ with a significance of $p=0.000$, this value means the linear regression equation can be accepted as an equation that shows the effect of parenting on prosocial behavior. The linear regression test show the regression equation: $\mathrm{y}=67.35+0.42 \mathrm{x}[\mathrm{y}=$ Prosocial behavior, $\mathrm{x}=$ Parenting style]. This equation informs that each increase in parenting scores by one unit then the prosocial behavior score will increase by sixty eight units.

Education is a necessity needed to shape individual behavior. Education can be given in various forms such as parenting, attitudes or behavior expressed by children in everyday life. With the application of certain parenting style, can also develop all aspects of individual development both cognitive, motor, language, arts and morals. Parenting has a very important role for the development of moral behavior. Euis [2] argues that parenting is a series of intensive interactions between parents and children so that the child has life skills. Whereas, suggested that parenting illustrates the interaction to express attitudes, behaviors, values, interests and expectations in caring for and meeting the needs. The results of this research analysis showed that there was an influence between the parenting style of cadet supervisor towards cadet prosocial behavior. The regression equation obtained is $\mathrm{y}=67.35+0.42 \mathrm{x}$, based on this equation it can be concluded that the higher the parenting pattern, the higher the cadet's ability to express prosocial behavior.

Based on the guidance of cadet parenting by BPSDM Transportation, it can be explained that the cadet's parenting consists of several indicators, namely: giving concrete instructions in the supervising process, giving encouragement for cadets to participate in educational activities, giving various perspective about their behavior, giving confidence gradually in forming responsibilities, consistent in applying the consequences of mistakes, helping and guiding to overcome difficulties for adjusting the education, and encouraging cadets to be active in collaborative activities of groups and organizations. In detail, it can be concluded that the more often cadet supervisor provide care in a persuasive way, give trust, encourage adjustments in education, be consistent in applying the consequences of mistakes, and encourage in group collaboration activities, have an impact on the tendency of cadets to 
express mutual sharing behavior in difficulties, cooperate, help, contributing and honesty among cadets regardless of majors or class will also be higher.

Santrock [5] explains that, democratic parenting style provides rational attitudes or logical thoughts and responsibility, perform actions that are suitable with the values and norms in society. In line with Diana Baumrind [6] states that in democratic parenting, parents and children will support each other and always provide logical considerations. According to cognitive perspective, an individual will engage in prosocial behavior depend on moral development, moral development can be developed by applying democratic guidance on parenting. Based on reinforcement approach [7], a person will take prosocial actions, especially helping behavior, because there is a reinforcement from the environment. In his research, an individual will take prosocial actions if he is rewarded for the positive actions, both material and social rewards. By getting rewards for their behavior, the individual tends to repeat the same behavior at different situations. Baron and Byrne [7] also explained that prosocial behavior can be increased by providing parenting that increases responsibility (Reducing environmental ambiguity and teaching responsible behavior), individuals will tend not to do prosocial in unclear situations for fear of doing wrong. In addition, responsibility at educational process needs to be trained by presenting various emergency situations that require quick and appropriate action to make individuals faster to make decisions in prosocial actions context.

Bjorklund and Bjorklund; Croacks and Stein [in Semiawan, Conny R. 1999] also argued that democratic parenting that teaches giving trust in a responsible manner and they will implement these rules voluntarily. According to Ilma's research [8] it is explained that parenting that shows warmth and control will increase the intensity of prosocial behavior, Aditia's Research also shows the same thing, her research proves that democratic parenting increases social awareness of children, then person who give or take prosocial actions also will experience psychological well-being that helps her/him to achieve wellbeing [9].

\section{Conclusions}

In general, the Prosocial Behavior of cadets is in the High and very high category, which means that most of Medan Aviation polytechnic cadets are able to take voluntary actions to help other individuals or groups of individuals

a. Based on the aspects of Prosocial behavior, Helping behavior has the highest percentage $(88 \%)$, which means that cadets have the willingness to help others by providing information or offering help to other individuals who are experiencing difficulties

b. The aspects of prosocial behavior of high and very high categories that have a percentage below $50 \%$ are donating and honesty. Besides these two aspects are also still in the low category of $0.5 \%$ for the donating and honesty aspects of $1 \%$. This data shows that cadets need to develop their willingness to donate, voluntarily share material and a willingness not to act fraudulently in conducting educational activities

c. In general, the pattern of parenting is in high and very high category, which means that the cadet supervisor has instructions that educate cadets to be responsible cadet through guidance and habituation

d. Based on the aspect of Parenting, the aspect with a very high or high percentage that is above $50 \%$ is the trustworthiness aspect, but there is still a moderate category $(22.5 \%)$ and low category (3.5\%). This means that most cadet supervisor have been able to give trust to cadets gradually for taking responsibility, but still require further development in developing trust in cadets 
e. Based on the aspect of Parenting, the aspects with very high percentage of categories which are below 50\% are sanctions and discussion activities in teams, this data shows that it needs further development in terms of giving or enforcing rules that apply consistently and rationally and the development of group activities that help cadets can be more synergized in a groups

f. There is a positive effect of parenting on the prosocial behavior of Medan aviation polytechnic cadet, the more often cadet supervisor provide supervising in a persuasive way, give trust, encourage adjustments in education, be consistent in applying the consequences of mistakes, and encourage in group collaboration activities, as an impact the cadet tendency to express sharing behavior in difficulties, cooperating, helping, contributing and honesty among cadets regardless of majors or forces will also be higher

\section{Recommendation}

a. This research was conducted only involving cadets in the Medan Aviation Polytechnic. For further research can involve cadets who are outside Medan, to involve other transportation cadets

b. It is necessary for mapping about prosocial behavior between another transportation cadets, so that it can be the basis for fostering aspects of prosocial behavior to prevent and suppress harassment or bullying between cadets while in the dormitory or outside the dormitory

c. For the Lecturer/Teaching Staff, can provide group assignments where the group assignments not only involve cadets from one major, but also involve other major or class to create mutual need environment between levels and majors

d. For the Department/Study Program, in certain periods such as semester or annual, simulation activities are given related to the department field, where this activity will be made a report and the cadet team consists of various major

e. For Cadet supervisor, they can design periodic routine activities to take prosocial actions, also called the "Prosocial Project" in determining their activities or the theme of their activities can be carried out in an atmosphere of discussion and the role of cadet supervisor as facilitators, not decision makers

f. For the Research Participant, doing Prosocial Behavior greatly affects the psychological well-being, while the act of harassment or bullying actually makes an individual more stressed, by doing simple prosocial actions every day can help to improve mental health.

\section{References}

[1] Schwab, Klaus, (2006), The Fourth Industrial Revolution. Switzerland: World Economic Forum.

[2] Euis, Sunarti. (2004), Mengasuh Anak dengan Hati. Jakarta: PT Elex Media Komputindo.

[3] Taylor, S. E. (2009), Psikologi Sosial. Jakarta: Kencana Prenada Media Group.

[4] Franzoi, S. L. (2009), Social Psychology. New York: The McGraw-Hill Companies, Inc.

[5] Santrock, Jhon. (2002), Perkembangan Masa Hidup Edisi ke-5 Jilid 1. Jakarta: Erlangga. 
[6] Casmini, (2007). Emotional Parenting: Dasar-dasar Pengasuhan Kecerdasan Emosi Anak. Yogyakarta: Pilar Media

[7] Raron, R. A. \& Byrne, D. (2005), Psikologi Sosial (10th ed). Jakarta: Erlangga.

[8] Conny R Semiawan. (1999), Perkembangan dan Belajar Peserta Didik. Jakarta: Departemen Pendidikan dan Kebudayaan.

[9] Megawati, Elisa (2016), Hubungan antara Perilaku Prososial dengan Psychological Well-Being pada Remaja. Fakultas Psikologi Udayana: Jurnal Psikologi Udayana. 